\title{
Impact of the COVID-19 pandemic on residents' clinical training and psychosocial well-being in Saudi Arabia's Western region
}

\section{Reem Alshareef ${ }^{1}$, Abdullah Al Zahrani ${ }^{1,2,3}$, Meshari Alzhrani $^{1}$, Abdulaziz Suwaidi ${ }^{1}$, Bander Alamry ${ }^{1}$}

${ }^{1}$ Department of Family Medicine, King Abdulaziz Medical City, Ministry of the National Guard - Health Affairs, Jeddah, Saudi Arabia, ${ }^{2}$ College of Medicine, King Saud Bin Abdulaziz University for Health Sciences, Jeddah, Saudi Arabia, ${ }^{3}$ King Abdullah International Medical Research Center, Jeddah, Saudi Arabia

\begin{abstract}
Background: The novel COVID-19 pandemic has imposed a significant burden on healthcare systems. Similarly, it has also affected the performance and well-being of the medical staff working during the pandemic. This study aims to evaluate the negative effect of COVID-19 pandemic on medical training and psychological well-being of resident doctors practicing in the Western region of Saudi Arabia. Methods: This is a quantitative cross-sectional study that included a survey distributed to resident physicians working in the western region in Saudi Arabia. The survey included questions on demographic data and factors influencing the academic training, attitude, and daily habits of the residents during the pandemic. Psychological impact was assessed using the Kessler Psychological Distress Scale. Data analysis was executed using IBM SPSS version 26. Results: A total of 121 residents responded to this survey. Of all respondents, $71.1 \%$ were junior residents, $66.9 \%$ had a medical specialty; and 33\% were family medicine physicians, followed by $17 \%$ from general surgery. In regard to work amid the pandemic, 36.1\% were in contact with confirmed COVID-19 patients, and 35.5\% had to work overtime during the pandemic. There was a non-significant difference detected between the residents regarding the factors negatively affecting their psychological well-being. Conclusion: Residents working during the pandemic in the Western area of Saudi Arabia were significantly affected by the pandemic from both professional and psychological perspectives. Further research on how the pandemic is affecting physicians in other areas in Saudi Arabia is needed.
\end{abstract}

Keywords: COVID-19, distress residents, pandemic, psychological impact, training

\section{Introduction}

SARS-CoV-2 is a newly identified virus that was first detected in the city of Wuhan in Hubei Province in China. ${ }^{[1]}$ The COVID-19 disease was defined as an epidemic in China after the reporting of multiple patients with new-onset, severe pneumonia with rapid progression and transmission. ${ }^{[2]}$ This novel virus belongs

Address for correspondence: Dr. Reem Alshareef, Department of Family Medicine, King Abdulaziz Medical City, P.O. BOX 21423-9515, Jeddah, Saudi Arabia. E-mail: alshareef.reem@gmail.com

Received: 21-10-2020

Revised: 09-12-2020

Accepted: 10-01-2021

Published: 30-07-2021

\begin{tabular}{|l|l|}
\hline \multicolumn{2}{|c|}{ Access this article online } \\
\hline Quick Response Code: & \\
&
\end{tabular}

to the coronavirus family, which has caused previous epidemics in Asia, including the MERS-CoV and SARS viruses. ${ }^{[3]}$

The major problem with COVID-19 infection is its speed of transmission. ${ }^{[4]}$ The virus started to spread globally within a very short time, which led to the announcement of COVID-19 as a pandemic in February 2020. ${ }^{[5]}$ This rapid spreading has put the most powerful healthcare systems around the world at risk of collapse. ${ }^{[6]}$ This is because patients with COVID-19 deteriorate rapidly, which increases their need for hospitalization and sometimes mechanical ventilation in severe cases. ${ }^{[7]}$

This is an open access journal, and articles are distributed under the terms of the Creative Commons Attribution-NonCommercial-ShareAlike 4.0 License, which allows others to remix, tweak, and build upon the work non-commercially, as long as appropriate credit is given and the new creations are licensed under the identical terms.

For reprints contact: WKHLRPMedknow_reprints@wolterskluwer.com

How to cite this article: Alshareef R, Al Zahrani A, Alzhrani M, Suwaidi A, Alamry B. Impact of the COVID-19 pandemic on residents' clinical training and psychosocial well-being in Saudi Arabia's Western region. J Family Med Prim Care 2021;10:2580-6. 
Accordingly, governments began to apply measures to reduce the spreading of the virus and thus lower the burden on healthcare systems. ${ }^{[8]}$ One of these measures was national lockdowns, which stopped most face-to-face services..$^{[9]}$ Despite this response, the virus continued to spread, and the pandemic affected not only healthcare systems but also medical staff, particularly the physicians. ${ }^{[10]}$ Due to the increased workload during the COVID-19 pandemic, many hospitals required their physicians to work overtime hours and sometimes days to care for COVID-19 patients. ${ }^{[1]}$ Additionally, most of the educational programs aimed at physicians, such as conferences and lectures, have stopped. ${ }^{[12,13]}$ All these changes have negatively impacted physicians, especially junior residents, in terms of their medical training and career progress. ${ }^{[13]}$ In an open survey conducted among ophthalmology residents in India, a significant number of the residents expressed negative impact on their learning especially the surgical training. ${ }^{[14]}$ In a local study, almost all surgical residents and fellows reported that their surgical exposure was reduced as a consequence of the pandemic. ${ }^{[15]}$

Furthermore, increasing mortality and infection among medical staff has had a significantly negative impact on physicians' psychological well-being. ${ }^{[16]}$ They have had to care for their colleagues or family members, sometimes watch them dying without being able to save them. Moreover, training residents expressed their concerns about transmitting the illness to their family, while nearly $38.4 \%$ of them were afraid of dying because of exposure. ${ }^{[17]}$ Also, as a result of the lockdown, significant number of the physicians' mental health and social lives were negatively affected. ${ }^{[18]}$ All these stresses have put the mental and psychological well-being of medical staff at risk. ${ }^{[1]]}$

To our knowledge, local and international data are scarce to address the issue of the affected medical training and psychosocial impact on both the medical and surgical residents in Saudi Arabia. Therefore, the present study aims to assess the negative impact of this pandemic on the academic education and the psychosocial well-being of the residents practicing in the Western region, Saudi Arabia.

\section{Methods}

\section{Study design}

This is a quantitative cross-sectional study that included resident physicians who were working in the Western region, Saudi Arabia, during the COVID-19 pandemic. The study included all medical and surgical residents without exclusion.

\section{Data collection}

The study utilized a questionnaire to assess the impact of the COVID-19 pandemic on academic training and the well-being of medical and surgical residents. The questionnaire was developed for this study and distributed through Google Forms. The study purpose was explained on the cover page of each questionnaire. The questionnaire included questions on demographic data and various factors affecting academic training, attitude, and daily habits of the residents during the pandemic. Psychological impact was assessed using the Kessler Psychological Distress Scale.

\section{Statistical analyses}

Descriptive analysis was carried out through totals and percentages for categorical data, while means and standard deviations were used for numerical data. Chi-square analysis was carried out to compare categorical variables, using a $P$ value of $<0.05$. All data analyses were conducted using IBM SPSS version 26 .

\section{Ethical considerations}

Approval for the study was obtained from the institutional ethics board. The study was carried out between June-August 2020. It was approved by the IRB office of King Abdullah International Medical Research Center (KAIMRC), Saudi Arabia. We received the approval on June 28. Participation was voluntary. The consent form was available on the first page of the questionnaire.

\section{Results}

A total of 121 residents from the western region in Saudi Arabia responded to the survey. Responses and respondent demographics are described below.

\section{Characteristics of the respondents}

Out of 121 respondents, $57 \%$ were female, $24 \%$ were smokers, and $59.5 \%$ were single. Additionally, $71.1 \%$ of the participants were junior residents, and $66.9 \%$ had a medical specialty, as shown in Table 1 and Figure 1.

\section{Working conditions during the COVID-19 pandemic}

Respondents were asked to evaluate their working conditions amid the COVID-19 pandemic. According to the responses, $36.1 \%$ of the residents were in contact with confirmed COVID-19 patients, while $42.1 \%$ were not in contact with confirmed or suspected cases. Additionally, the nasopharyngeal swab was done for $33.1 \%$ of the residents, and $35.5 \%$ had to work overtime during the pandemic, as shown in Table 2.

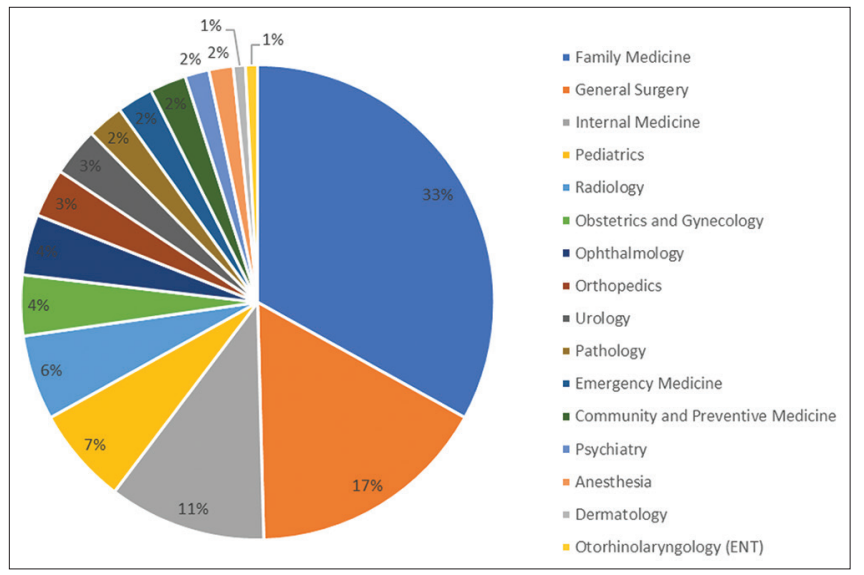

Figure 1: Respondent medical specialty 


\section{Teaching and training during the COVID-19} pandemic

Participants were also asked how much the COVID-19 pandemic has affected their teaching and training. Of all residents, $27.3 \%$ mentioned that the number of surgeries had been extremely affected. More than one-third of the residents felt their program teaching activity and the number of clinics, studying hours, conferences and lectures being offered had been extremely affected. However, $38.8 \%$ stated that the variety of clinical cases was moderately affected.

Furthermore, almost three-quarters $(77.7 \%)$ of the resident responded that their clinical rotations were changed, and $46.3 \%$

\begin{tabular}{|c|c|c|c|}
\hline \multicolumn{4}{|c|}{ Table 1: Respondents' characteristics } \\
\hline & & Total & Percent \\
\hline \multirow[t]{2}{*}{ Gender } & Male & 52 & 43.0 \\
\hline & Female & 69 & 57.0 \\
\hline \multirow[t]{3}{*}{ Smoking history } & Non-Smoker & 91 & 75.2 \\
\hline & Smoker & 29 & 24.0 \\
\hline & Ex-Smoker & 1 & 0.8 \\
\hline \multirow[t]{3}{*}{ Marital status } & Single & 72 & 59.5 \\
\hline & Married & 48 & 39.7 \\
\hline & Divorced & 1 & 0.8 \\
\hline \multirow[t]{2}{*}{ Level of training } & Junior & 86 & 71.1 \\
\hline & Senior & 35 & 28.9 \\
\hline \multirow[t]{2}{*}{ Medical specialty } & Medical & 81 & 66.9 \\
\hline & Surgical & 40 & 33.1 \\
\hline
\end{tabular}

were moved from their departments to help other departments caring for COVID-19 patients, as shown in Table 3.

Respondents were also asked how much their medical training was negatively affected by the pandemic; $44 \%$ described their training as extremely affected, as shown in Figure 2.

\section{Psychological impact on the residents during the last month amid the COVID-19 pandemic}

In regard to the participants' emotions during this pandemic, more than one-third said they felt tired for no good reason some of the time, and the majority felt nervous, hopeless, restless, or depressed at least some of the time and that all tasks involved a lot of effort, as shown in Table 4.

\section{Behaviors during the last month}

Other behaviors were also evaluated. About 78\% mentioned they always wore masks when they left home. More than half of the physicians always performed proper hand hygiene, routinely disinfected surfaces after contact with sick patients, and found that their social life has been affected. Additionally, almost one-third of the physicians found that they were sometimes having difficulty falling or staying asleep, adopting bad eating habits, and could not maintain an optimal body weight, as shown in Table 5.

\section{Table 2: Respondents' working conditions during the COVID-19 pandemic}

\begin{tabular}{|c|c|c|c|}
\hline & & Total & Percent \\
\hline \multirow[t]{4}{*}{ During the COVID-19 pandemic, have you been...? } & In contact with COVID-19 patients & 44 & 36.1 \\
\hline & Suspected to have COVID-19 & 10 & 8.2 \\
\hline & Suspected to have COVID-19, in contact with COVID-19 patients & 16 & 13.2 \\
\hline & None & 51 & 42.1 \\
\hline \multirow[t]{2}{*}{ Have you received a nasopharyngeal swab for COVID-19? } & Yes & 40 & 33.1 \\
\hline & No & 81 & 66.9 \\
\hline \multirow[t]{2}{*}{ Have you been working overtime? } & Yes & 43 & 35.5 \\
\hline & No & 78 & 64.5 \\
\hline
\end{tabular}

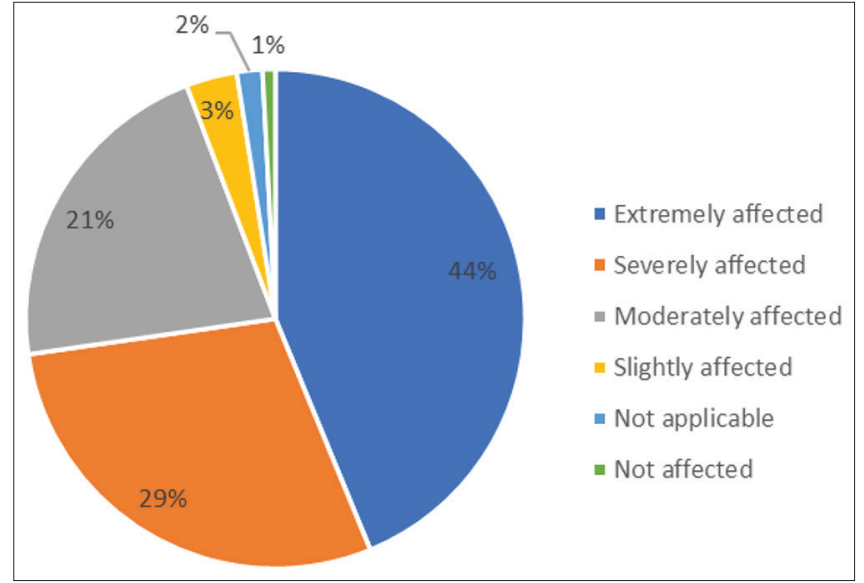

Figure 2: COVID-19 pandemic impact on the medical training among the residents

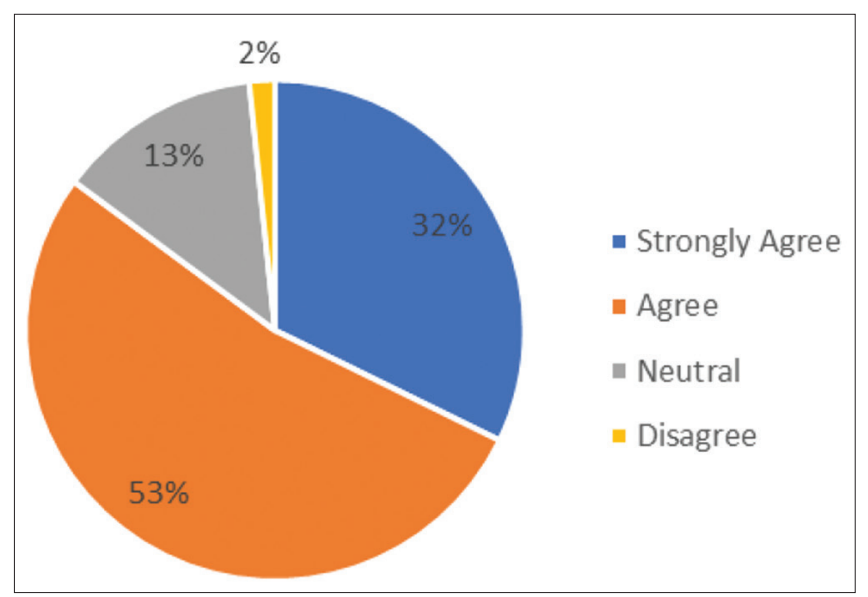

Figure 3: COVID-19 pandemic impact on psychological well-being of the residents 


\begin{tabular}{|c|c|c|c|}
\hline & & Total & Percent \\
\hline \multirow[t]{6}{*}{ Number of operations } & Extremely affected & 33 & 27.3 \\
\hline & Severely affected & 9 & 7.4 \\
\hline & Moderately affected & 8 & 6.6 \\
\hline & Slightly affected & 4 & 3.3 \\
\hline & Not affected & 5 & 4.1 \\
\hline & Not applicable & 62 & 51.2 \\
\hline \multirow[t]{6}{*}{ Program teaching activity } & Extremely affected & 42 & 34.7 \\
\hline & Severely affected & 18 & 14.9 \\
\hline & Moderately affected & 26 & 21.5 \\
\hline & Slightly affected & 17 & 14.0 \\
\hline & Not affected & 17 & 14.0 \\
\hline & Not applicable & 1 & 0.8 \\
\hline \multirow[t]{6}{*}{ Variety of clinical cases } & Extremely affected & 35 & 28.9 \\
\hline & Severely affected & 24 & 19.8 \\
\hline & Moderately affected & 47 & 38.8 \\
\hline & Slightly affected & 10 & 8.3 \\
\hline & Not affected & 2 & 1.7 \\
\hline & Not applicable & 3 & 2.5 \\
\hline \multirow{6}{*}{$\begin{array}{l}\text { Conferences and lectures } \\
\text { offered }\end{array}$} & Extremely affected & 44 & 36.4 \\
\hline & Severely affected & 29 & 24.0 \\
\hline & Moderately affected & 20 & 16.5 \\
\hline & Slightly affected & 11 & 9.1 \\
\hline & Not affected & 15 & 12.4 \\
\hline & Not applicable & 2 & 1.7 \\
\hline \multirow[t]{6}{*}{ Number of clinics } & Extremely affected & 38 & 31.4 \\
\hline & Severely affected & 17 & 14.0 \\
\hline & Moderately affected & 17 & 14.0 \\
\hline & Slightly affected & 24 & 19.8 \\
\hline & Not affected & 7 & 5.8 \\
\hline & Not applicable & 18 & 14.9 \\
\hline \multirow[t]{6}{*}{ Studying hours } & Extremely affected & 44 & 36.4 \\
\hline & Severely affected & 24 & 19.8 \\
\hline & Moderately affected & 24 & 19.8 \\
\hline & Slightly affected & 10 & 8.3 \\
\hline & Not affected & 17 & 14.0 \\
\hline & Not applicable & 2 & 1.7 \\
\hline \multirow{2}{*}{$\begin{array}{l}\text { During this COVID-19 } \\
\text { pandemic, your clinical } \\
\text { rotations were }\end{array}$} & Changed & 94 & 77.7 \\
\hline & Not changed & 27 & 22.3 \\
\hline \multirow{2}{*}{$\begin{array}{l}\text { Were you redeployed from your } \\
\text { department to work with other } \\
\text { teams involved in COVID-19 } \\
\text { disaster management? }\end{array}$} & Yes & 56 & 46.3 \\
\hline & No & 65 & 53.7 \\
\hline
\end{tabular}

\section{Social behaviors during COVID-19}

Turning to social behaviors, $76 \%$ of the physicians performed less than 100 minutes of weekly exercise, 39.6\% were smoking more than they used to, and $79.3 \%$ were bothered about going to places with more than 50 people, as shown in Table 5 .

The residents were also asked how much they would agree that the pandemic had negatively affected their psychological well-being; one-third of the physicians strongly agreed, and half agreed that their psychological well-being was negatively affected, as shown in Figure 3.
Table 4: Psychological Assessment of the participants using the Kessler Psychological Distress Scale

\begin{tabular}{|c|c|c|c|}
\hline & & Total & Percent \\
\hline \multirow{5}{*}{$\begin{array}{l}\text { In the past four weeks, about how } \\
\text { often did you feel tired for no good } \\
\text { reason? }\end{array}$} & All the time & 22 & 18.2 \\
\hline & Most of the time & 34 & 28.1 \\
\hline & Some of the time & 44 & 36.4 \\
\hline & A little of the time & 19 & 15.7 \\
\hline & None of the time & 2 & 1.7 \\
\hline \multirow{5}{*}{$\begin{array}{l}\text { In the past four weeks, about how } \\
\text { often did you feel nervous? }\end{array}$} & All the time & 16 & 13.2 \\
\hline & Most of the time & 32 & 26.4 \\
\hline & Some of the time & 53 & 43.8 \\
\hline & A little of the time & 18 & 14.9 \\
\hline & None of the time & 2 & 1.7 \\
\hline \multirow{5}{*}{$\begin{array}{l}\text { In the past four weeks, about how } \\
\text { often did you feel so nervous that } \\
\text { nothing could calm you down? }\end{array}$} & All the time & 8 & 6.6 \\
\hline & Most of the time & 14 & 11.6 \\
\hline & Some of the time & 33 & 27.3 \\
\hline & A little of the time & 40 & 33.1 \\
\hline & None of the time & 26 & 21.5 \\
\hline \multirow{5}{*}{$\begin{array}{l}\text { In the past four weeks, about how } \\
\text { often did you feel hopeless? }\end{array}$} & All the time & 10 & 8.3 \\
\hline & Most of the time & 25 & 20.7 \\
\hline & Some of the time & 38 & 31.4 \\
\hline & A little of the time & 22 & 18.2 \\
\hline & None of the time & 26 & 21.5 \\
\hline \multirow{5}{*}{$\begin{array}{l}\text { In the past four weeks, about } \\
\text { how often did you feel restless or } \\
\text { fidgety? }\end{array}$} & All the time & 9 & 7.4 \\
\hline & Most of the time & 28 & 23.1 \\
\hline & Some of the time & 33 & 27.3 \\
\hline & A little of the time & 32 & 26.4 \\
\hline & None of the time & 19 & 15.7 \\
\hline \multirow{5}{*}{$\begin{array}{l}\text { In the past four weeks, about how } \\
\text { often did you feel so restless you } \\
\text { could not sit still? }\end{array}$} & All the time & 8 & 6.6 \\
\hline & Most of the time & 9 & 7.4 \\
\hline & Some of the time & 38 & 31.4 \\
\hline & A little of the time & 29 & 24.0 \\
\hline & None of the time & 37 & 30.6 \\
\hline \multirow{5}{*}{$\begin{array}{l}\text { In the past four weeks, about how } \\
\text { often did you feel depressed? }\end{array}$} & All the time & 17 & 14.0 \\
\hline & Most of the time & 23 & 19.0 \\
\hline & Some of the time & 48 & 39.7 \\
\hline & A little of the time & 18 & 14.9 \\
\hline & None of the time & 15 & 12.4 \\
\hline \multirow{5}{*}{$\begin{array}{l}\text { In the past four weeks, about how } \\
\text { often did you feel that most tasks } \\
\text { took more effort than usual? }\end{array}$} & All the time & 14 & 11.6 \\
\hline & Most of the time & 29 & 24.0 \\
\hline & Some of the time & 41 & 33.9 \\
\hline & A little of the time & 30 & 24.8 \\
\hline & None of the time & 7 & 5.8 \\
\hline \multirow{5}{*}{$\begin{array}{l}\text { In the past four weeks, about } \\
\text { how often did you feel so sad that } \\
\text { nothing could cheer you up? }\end{array}$} & All the time & 11 & 9.1 \\
\hline & Most of the time & 19 & 15.7 \\
\hline & Some of the time & 33 & 27.3 \\
\hline & A little of the time & 34 & 28.1 \\
\hline & None of the time & 24 & 19.8 \\
\hline \multirow{5}{*}{$\begin{array}{l}\text { In the past four weeks, about how } \\
\text { often did you feel worthless? }\end{array}$} & All the time & 10 & 8.3 \\
\hline & Most of the time & 14 & 11.6 \\
\hline & Some of the time & 28 & 23.1 \\
\hline & A little of the time & 30 & 24.8 \\
\hline & None of the time & 39 & 32.2 \\
\hline
\end{tabular}

Factors influencing training and psychological well-being during the COVID-19 pandemic

To identify the residents who were more likely to have their psychological well-being and their training affected by the 
Table 5: Participants' Behavior and responses during the last month

\begin{tabular}{|c|c|c|c|}
\hline & & Count & Percent \\
\hline \multirow[t]{4}{*}{ Wearing a mask when leaving home } & Always & 95 & 78.5 \\
\hline & Often & 12 & 9.9 \\
\hline & Sometimes & 12 & 9.9 \\
\hline & Rarely & 2 & 1.7 \\
\hline \multirow[t]{3}{*}{ How many minutes per week do you exercise? } & Less than 100 minutes & 92 & 76.0 \\
\hline & $100-150$ minutes & 12 & 9.9 \\
\hline & More than 150 minutes & 17 & 14.0 \\
\hline \multirow[t]{2}{*}{ For smokers, have you been smoking more? } & Yes & 21 & 39.6 \\
\hline & No & 32 & 60.3 \\
\hline \multirow[t]{2}{*}{ Does it bother you now to go to places with more than 50 people? } & Yes & 96 & 79.3 \\
\hline & No & 25 & 20.7 \\
\hline
\end{tabular}

\section{Table 6: Chi-square comparison on the pandemic negative impact on the medical training}

\begin{tabular}{|c|c|c|c|c|c|c|c|c|}
\hline & & $\begin{array}{l}\text { Extremely } \\
\text { affected }\end{array}$ & $\begin{array}{l}\text { Severely } \\
\text { affected }\end{array}$ & $\begin{array}{l}\text { Moderately } \\
\text { affected }\end{array}$ & $\begin{array}{l}\text { Slightly } \\
\text { affected }\end{array}$ & $\begin{array}{c}\text { Not } \\
\text { affected }\end{array}$ & $\begin{array}{c}\text { Not } \\
\text { applicable }\end{array}$ & $P *$ \\
\hline \multirow[t]{2}{*}{ Gender } & Male & $28.3 \%$ & $54.3 \%$ & $57.7 \%$ & $50.0 \%$ & $100.0 \%$ & $0.0 \%$ & 0.039 \\
\hline & Female & $71.7 \%$ & $45.7 \%$ & $42.3 \%$ & $50.0 \%$ & $0.0 \%$ & $100.0 \%$ & \\
\hline \multirow[t]{2}{*}{ Level of training } & Junior & $54.7 \%$ & $85.7 \%$ & $84.6 \%$ & $50.0 \%$ & $100.0 \%$ & $100.0 \%$ & 0.011 \\
\hline & Senior & $45.3 \%$ & $14.3 \%$ & $15.4 \%$ & $50.0 \%$ & $0.0 \%$ & $0.0 \%$ & \\
\hline \multirow[t]{2}{*}{ Specialty } & Medical & $71.7 \%$ & $68.6 \%$ & $53.8 \%$ & $50.0 \%$ & $100.0 \%$ & $100.0 \%$ & 0.467 \\
\hline & Surgical & $28.3 \%$ & $31.4 \%$ & $46.2 \%$ & $50.0 \%$ & $0.0 \%$ & $0.0 \%$ & \\
\hline \multirow[t]{3}{*}{ Smoking } & Smoker & $34.0 \%$ & $28.6 \%$ & $3.8 \%$ & $0.0 \%$ & $0.0 \%$ & $0.0 \%$ & 0.176 \\
\hline & Non-smoker & $66.0 \%$ & $68.6 \%$ & $96.2 \%$ & $100.0 \%$ & $100.0 \%$ & $100.0 \%$ & \\
\hline & Ex-smoker & $0.0 \%$ & $2.9 \%$ & $0.0 \%$ & $0.0 \%$ & $0.0 \%$ & $0.0 \%$ & \\
\hline \multirow[t]{2}{*}{ Working overtime } & Yes & $41.5 \%$ & $40.0 \%$ & $23.1 \%$ & $25.0 \%$ & $0.0 \%$ & $0.0 \%$ & 0.449 \\
\hline & No & $58.5 \%$ & $60.0 \%$ & $76.9 \%$ & $75.0 \%$ & $100.0 \%$ & $100.0 \%$ & \\
\hline
\end{tabular}

${ }^{* p}<0.05$.

Table 7: Chi-square comparison on the pandemic negative impact on the psychological well-being of the residents

\begin{tabular}{|c|c|c|c|c|c|c|}
\hline & & Strongly Agree & Agree & Neutral & Disagree & $P^{*}$ \\
\hline \multirow[t]{2}{*}{ Gender } & Male & $28.2 \%$ & $50.0 \%$ & $50.0 \%$ & $50.0 \%$ & 0.163 \\
\hline & Female & $71.8 \%$ & $50.0 \%$ & $50.0 \%$ & $50.0 \%$ & \\
\hline \multirow[t]{2}{*}{ Level of training } & Junior & $82.1 \%$ & $62.5 \%$ & $75.0 \%$ & $100.0 \%$ & 0.138 \\
\hline & Senior & $17.9 \%$ & $37.5 \%$ & $25.0 \%$ & $0.0 \%$ & \\
\hline \multirow[t]{2}{*}{ Specialty } & Medical & $59.0 \%$ & $71.9 \%$ & $62.5 \%$ & $100.0 \%$ & 0.399 \\
\hline & Surgical & $41.0 \%$ & $28.1 \%$ & $37.5 \%$ & $0.0 \%$ & \\
\hline \multirow[t]{3}{*}{ Smoking } & Smoker & $23.1 \%$ & $25.0 \%$ & $18.8 \%$ & $50.0 \%$ & 0.274 \\
\hline & Non-smoker & $76.9 \%$ & $75.0 \%$ & $75.0 \%$ & $50.0 \%$ & \\
\hline & Ex-smoker & $0.0 \%$ & $0.0 \%$ & $6.3 \%$ & $0.0 \%$ & \\
\hline \multirow[t]{2}{*}{ Working overtime } & Yes & $35.9 \%$ & $42.2 \%$ & $12.5 \%$ & $0.0 \%$ & 0.109 \\
\hline & No & $64.1 \%$ & $57.8 \%$ & $87.5 \%$ & $100.0 \%$ & \\
\hline
\end{tabular}

pandemic, their overall level of impact was compared over different variables using Chi-square tests $(p<0.05)$. It was found that the female residents and the junior residents' training were negatively affected compared to their peers $(\mathrm{p}=0.039,0.011$, respectively), as shown in Table 6.

On the other hand, no significant difference was detected when comparing gender, level of training, specialty, smoking, or working overtime regarding their negative influence on psychological well-being, as shown in Table 7.

\section{Discussion}

The COVID-19 pandemic has not only affected healthcare resources and patients' lives negatively, but it has also had a negative impact on the life of physicians from different perspectives. ${ }^{\left[{ }^{[0]}\right.}$ Due to lockdowns and social distancing measures, the number of clinical rounds and lectures have been significantly reduced, and physicians' workloads have also increased, both of which may have put their psychological well-being at risk. ${ }^{[21]}$ In Saudi Arabia, the pandemic struck particularly hard, which has increased the burden on Saudi medical staff. ${ }^{[2]}$ 
The impact of COVID-19 on medical staff has been examined in different settings. Among radiology medical trainees, remarkable increased workload and clinical reassignment to other departments were reported during the pandemic. ${ }^{[23]}$ Further, the medical trainees were exposed to an increased financial burden due to higher costs of childcare services during the pandemic, which they needed because of their increased working hours. ${ }^{[23]}$ In the present study, almost one-third of the respondents had to work overtime during the pandemic; however, financial burdens were not increased, which could be because the majority of participants were juniors and singles.

The incidence of depression and anxiety were significantly higher among physicians who had duties with the COVID-19 patients in tertiary hospitals, with the female physicians being the most affected group. ${ }^{[6]}$ Higher rate of anxiety were experienced by surveyed training residents in the US, especially among females and junior residents. ${ }^{[15]}$ In the present study, female and junior physicians reported the highest negative impact to their training during the pandemic; however, there was no significant impact on psychological well-being among all physicians.

The present study not only examined the pandemic's negative influence on psychological well-being but also examined its negative impact on medical training. Findings demonstrated that medical training was affected in terms of the number of clinical rounds, study hours, operations, and lectures and conferences. Primary healthcare physicians are among the frontline physicians to address stressors brought by the pandemic. Even with the unprecedented calls for "virtual visits", ${ }^{24]}$ the health care providers should be aware of these impacts on the academic training and psychosocial well-being of the residents.

It should be noted that the present investigation had some limitations. This study included residents from one region of Saudi Arabia, which makes the extrapolation of the results more challenging. Additionally, due to the survey design, the study outcomes are based on the subjective opinion of the included physicians, which might affect the reliability of the results.

\section{Conclusion}

The COVID-19 pandemic has significantly influenced the psychological well-being and medical training of residents working in the Western area of Saudi Arabia. We found that medical training and academic activities were extremely affected during the COVID-19 pandemic. Most of the residents had to change their clinical rotations and almost half of them worked in departments to treat COVID-19 patients. Accordingly, decision-makers in the healthcare sector should consider these findings to prevent any additional burden on medical staff in future pandemics.

\section{Availability of data and materials}

The data that support the findings of this study are available from the corresponding author upon request.

\section{Abbreviations}

COVID-19: coronavirus that causes coronavirus disease 2019

SARS-CoV-2: Severe acute respiratory syndrome coronavirus 2

\section{Ethics Declarations}

This study was approved by the ethics committee of King Abdullah International Medical Research Center. written informed consent was obtained from all participants.

\section{Financial support and sponsorship}

Nil.

\section{Conflicts of interest}

There are no conflicts of interest.

\section{References}

1. Torales J, O'Higgins M, Castaldelli-Maia JM, Ventriglio A. The outbreak of COVID-19 coronavirus and its impact on global mental health. Int J Soc Psychiatry 2020;66:317-20.

2. World Health Organization. Modes of transmission of virus causing COVID-19: Implications for IPC precaution recommendations [Internet]. 2020 [cited 2020 Jun 12]. Available from: https://www.who.int/news-room/commentaries/ detail/modes-of-transmission-of-virus-causing-covid-19implications-for-ipc-precaution-recommendations.

3. Cao W, Fang Z, Hou G, Han M, Xu X, Dong J, et al. The psychological impact of the COVID-19 epidemic on college students in China. Psychiatry Res 2020;287:112934.

4. Chew NW, Lee GK, Tan BYQ, Jing M, Goh Y, Ngiam NJ, et al. A multinational, multicentre study on the psychological outcomes and associated physical symptoms amongst healthcare workers during COVID-19 outbreak. Brain Behav Immun 2020;88:559-65.

5. Holmes EA, O'Connor RC, Perry VH, Tracey I, Wessely S, Arseneault L, et al. Multidisciplinary research priorities for the COVID-19 pandemic: A call for action for mental health science. Lancet Psychiatry 2020;7:547-60.

6. Tan BYQ, Chew NWS, Lee GKH, Jing M, Goh Y, Yeo LL, et al. Psychological impact of the COVID-19 pandemic on health care workers in Singapore. Ann Intern Med 2020;173:317-20.

7. Pfefferbaum B, North CS. Mental health and the Covid-19 pandemic. N Engl J Med 2020;383:510-2.

8. Li Z, Ge J, Yang M, Feng J, Qiao M, Jiang R, et al. Vicarious traumatization in the general public, members, and nonmembers of medical teams aiding in COVID-19 control. Brain Behav Immun 2020;88:916-9.

9. Wang C, Pan R, Wan X, Tan Y, Xu L, Ho CS, et al. Immediate psychological responses and associated factors during the initial stage of the 2019 coronavirus disease (COVID-19) epidemic among the general population in China. Int $\mathrm{J}$ Environ Res Public Health 2020;17:1729.

10. Kang L, Ma S, Chen M, Yang J, Wang Y, Li R, et al. Impact on mental health and perceptions of psychological care among medical and nursing staff in Wuhan during the 2019 novel coronavirus disease outbreak: A cross-sectional study. Brain Behav Immun 2020;87:11-7.

11. Rosen GH, Murray KS, Greene KL, Pruthi RS, Richstone L, Mirza M. Effect of COVID-19 on urology residency training: 
A nationwide survey of program directors by the Society of Academic Urologists. J Urol 2020;204:1039-45.

12. Fero KE, Weinberger JM, Lerman S, Bergman J. Perceived impact of urologic surgery training program modifications due to COVID-19 in the United States. Urology 2020;143:62-7.

13. Amparore D, Claps F, Cacciamani GE, Esperto F, Fiori C, Liguori $\mathrm{G}$, et al. Impact of the COVID-19 pandemic on urology residency training in Italy. Minerva Urol Nefrol 2020;72:505-9.

14. Mishra D, Nair AG, Gandhi RA, Gogate PJ, Mathur S, Bhushan P, et al. The impact of COVID-19 related lockdown on ophthalmology training programs in India - Outcomes of a survey. Indian J Ophthalmol 2020;68:999-1004.

15. Rana T, Hackett C, Quezada T, Chaturvedi A, Bakalov V, Leonardo J, et al. Medicine and surgery residents' perspectives on the impact of COVID-19 on graduate medical education. Med Educ Online 2020;25:1818439.

16. Huang JZ, Han MF, Luo TD, Ren AK, Zhou XP. Mental health survey of medical staff in a tertiary infectious disease hospital for COVID-19. Zhonghua Lao Dong Wei Sheng Zhi Ye Bing Za Zhi 2020;38:192-5.

17. Osama M, Zaheer F, Saeed H, Anees K, Jawed Q, Syed SH, et al. Impact of COVID-19 on surgical residency programs in Pakistan; A residents' perspective. Do programs need formal restructuring to adjust with the "new normal"? A cross-sectional survey study. Int J Surg 2020;79:252-6.
18. Alhaj AK, Al-Saadi T, Mohammad F, Alabri S. Neurosurgery residents perspective on the COVID-19: Knowledge, readiness, and impact of this pandemic. World Neurosurg 2020;139:e848-58.

19. Du J, Dong L, Wang T, Yuan C, Fu R, Zhang L, et al. Psychological symptoms among frontline healthcare workers during COVID-19 outbreak in Wuhan. Gen Hosp Psychiatry 2020;67:144-5.

20. Chung JPY, Yeung WS. Staff Mental Health Self-Assessment During the COVID-19 Outbreak. East Asian Arch Psychiatry. 2020;30:34.

21. Chen Q, Liang M, Li Y, Guo J, Fei D, Wang L, et al. Mental health care for medical staff in China during the COVID-19 outbreak. Lancet Psychiatry 2020;7:e15-6.

22. Lai J, Ma S, Wang Y, Cai Z, Hu J, Wei N, et al. Factors associated with mental health outcomes among health care workers exposed to coronavirus disease 2019. JAMA Netw Open 2020;3:e203976.

23. Alvin MD, George E, Deng F, Warhadpande S, Lee SI. The impact of COVID-19 on radiology trainees. Radiology 2020;296:246-8.

24. Sinha S, Kern LM, Gingras LF, Reshetnyak E, Tung J, Pelzman F, et al. Implementation of video visits during COVID-19: Lessons learned from a primary care practice in New York City. Front Public Health 2020;8:514. 